\title{
NONSPECIFIC INFECTIOUS DISEASES IN PREHISTORIC SAN PEDRO DE ATACAMA, NORTHERN CHILE
}

\author{
ENFERMEDADES INFECCIOSAS NO-ESPECÍFICAS EN POBLACIONES \\ PREHISTÓRICAS DE SAN PEDRO DE ATACAMA, NORTE DE CHILE
}

\author{
Pedro José Tótora Da-Gloria ${ }^{1}$, Walter Alves Neves², Maria Antonietta Costa Junqueira², \\ and Rafael Bartolomucci ${ }^{4}$
}

\begin{abstract}
The region of San Pedro de Atacama, Northern Chile, has undergone several cultural and social changes after humans settled in Atacama Desert around 500 BC. The Atacameño people experienced the highest degree of social and cultural changes between 400 and $900 \mathrm{AD}$ when they were assimilated into the Tiwanaku trade and political web that influenced most of the Central-Southern Andes. Under the influence of Tiwanaku, San Pedro de Atacama experienced its greatest economic development. Prior analyses of local human skeletal remains have shown a significant increase in the stature of the local population during the same period. In this paper, we investigate the impact of the Tiwanaku influence on the local epidemiological profile using the incidence of periostitis and osteomyelitis as indicators of biological stress. Surprisingly, the best epidemiological condition occurred during the final phase of influence of Tiwanaku (910-960 AD), and not during the apex influence (480-920 AD), as expected by the archaeological context. We suggest that population growth and aggregation may have counteracted the benefits of improved nutrition during the peak Tiwanaku influence. A severe drought occurred between 1,100 and 1,400 AD in Northern Chile. This could also explain the marked increase of bone infections in the post-Tiwanaku period (920-1,240 AD).
\end{abstract}

Key words: Atacama Desert, bioarchaeology, biological quality of life, Tiwanaku, epidemiology.

La región de San Pedro de Atacama, Norte de Chile, experimentó varios cambios culturales y sociales desde los primeros asentamientos humanos alrededor de los 500 a.C., aunque los más altos grados de cambio los sufrieron los atacameños entre 400 y 900 d.C., cuando fueron establecidas conexiones con la red cultural y de intercambio de Tiwanaku, cultura ésta que ejerció influencia sobre la mayor parte de los Andes Centro-Sur. Bajo esta influencia, San Pedro de Atacama tuvo su mayor desarrollo económico. Análisis anteriores de restos esqueletales humanos han mostrado un significativo aumento en la estatura de la población local durante el mismo período. En este trabajo investigamos el impacto de la influencia Tiwanaku en el perfil epidemiológico local, usando la incidencia de periostitis y de osteomielitis como indicadores de estrés biológico. La mejor situación epidemiológica ocurrió durante el final de la fase de influencia de Tiwanaku (910-960 d.C.) y no durante el ápice de esta influencia (480-920 d.C.), como sería de esperar por el contexto arqueológico. Sugerimos que el crecimiento poblacional y la consecuente congregación pudo haber contrarrestado los beneficios de una mejor nutrición durante el auge de la influencia altiplánica. Una severa sequía ocurrió entre 1.100 y 1.400 d.C. en el Norte de Chile, lo que podría explicar el marcado aumento de las infecciones óseas en el período post-Tiwanaku (920-1.240 d.C.).

Palabras claves: desierto de Atacama, bioarqueología, calidad de vida biológica, Tiwanaku, epidemiología.

San Pedro de Atacama is located in the Atacama Desert, Northern Chile (Figure 1), one of the most arid regions of the planet. Permanent settlement in the small oasis within the desert was possible only after the development of agriculture and camelid husbandry in the Andes (Llagostera 1996). Archaeological data tell us that the first farmers in the Oasis of Atacama were settled around $500 \mathrm{BC}$ using maize as their main staple (Núñez 1992). The Atacameño culture lasted until the arrival of the Spaniards in the region in the 16th century. During the period that separates the genesis of the Atacameño culture and its collapse subsequent to European arrival, the local population experienced several changes (Llagostera and Costa 1984).

1 Department of Anthropology, The Ohio State University, 4034 Smith Laboratory 174 W. 18th Avenue, Columbus, OH 43210, USA. da-gloria.1@buckeyemail.osu.edu

2 Laboratório de Estudos Evolutivos Humanos, Instituto de Genética e Biologia Evolutiva, Universidade de São Paulo, Brasil. waneves@ib.usp.br

3 Instituto de Investigaciones Arqueológicas y Museo, Universidad Católica del Norte. San Pedro de Atacama, Chile. ma.costa@vtr.net

4 Museu de Arqueologia e Etnologia, Universidade de São Paulo, Brasil. rbarto@gmail.com

Recibido: mayo 2007. Aceptado: octubre 2008, revisado: febrero 2011. 


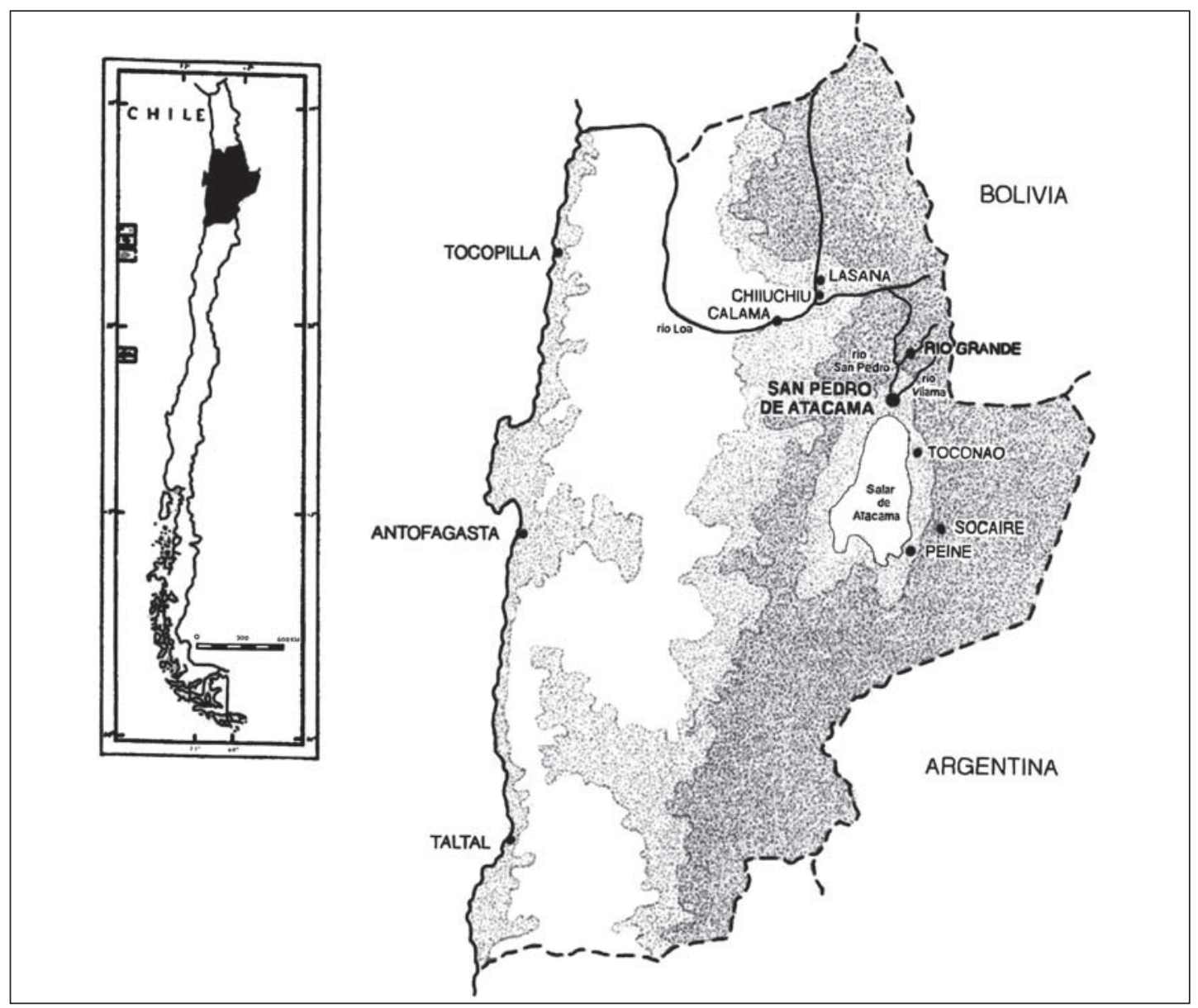

Figure 1. Northern Chile map showing Atacama Salar (adapted from Costa et al. 2004).

Mapa del norte de Chile mostrando el salar de Atacama (adaptado de Costa et al. 2004).

One of the most dramatic of these changes occurred between 400 and $900 \mathrm{AD}$, triggered by the rise (and expansion) of Tiwanaku located in the Titicaca valley, in the Bolivian altiplano (Janusek 2002; Kolata 1993). Tiwanaku culture had a profound impact on various surrounding populations, including San Pedro de Atacama in Northern Chile (Bermann 1997; Browman 1980; Kolata 1993; Neves et al. 1996; Stanish and Steadman 1994; Torres-Rouff 2008). During the peak of Tiwanaku influence in the region, there is archaeological evidence for a more elaborate material culture (Le Paige 1965; Llagostera et al. 1988; Rodman 1992) and increases in social complexity and stratification (Llagostera 1996; Llagostera 2004). San Pedro de Atacama appears to have received a strong religious and economic influence, although low population input from Tiwanaku has been detected (Knudson
2008). Further, all the oases were occupied during this period, showing an increase in the density of the settlements (Llagostera and Costa 1999).

After the collapse of the Tiwanaku capital around $900 \mathrm{AD}$ and the rupture of its sociopolitical and commercial network, the Atacama population experienced an impoverishment of the material culture associated with an increase in social tension (Llagostera 2004). A regional drought is pointed out as a significant factor in the social changes occurred in the central-southern Andes (Binford et al. 1997; Ortloff and Kolata 1993).

Since 1986, two of us (WAN and MAC) have been assessing the impact of Tiwanaku influence on the local population of San Pedro de Atacama. Human skeletal remains uncovered from three burial sites of the region have been intensively analyzed for this purpose. These sites cover the main periods 
of the local prehistory (Costa 1988; Costa and Neves 1990; Neves et al. 1996). It has been already demonstrated (Neves and Costa 1998) that at least one widely accepted osteological marker of quality of life-adult stature (Steckel 1995)- indicates an improvement in the nutritional conditions during the Tiwanaku period compared with the situation before and after the altiplanic influence. This picture was corroborated more recently (Costa et al. 2004) by the assessment of caries and tooth wear in the same skeletons. These markers also suggest a diet richer in animal protein during the influence of Tiwanaku in San Pedro (Neves et al. 2000).

In this paper, we assess the impact of Tiwanaku on the quality of life in Atacama, examining the incidence and distribution of nonspecific infectious disease in the local population. We work with the hypothesis that the influence of Tiwanaku improved the quality of life of Atacameño people. This hypothesis is supported by both the degree of sophistication of the local material culture during the Tiwanaku influence and the high stature of the population during this same period. In short, we expect that the infections, opposite to stature, will be lower during the Tiwanaku apex.

\section{Material and Methods}

The skeletal material used in this work comprises 156 adults and 88 subadults (less than 19 years) skeletons uncovered from the sites of Solcor-3, Quitor-6 and Coyo-3 (Table 1 and Figure 2). These three sites are located in the oasis of San Pedro de Atacama and were excavated during the last 25 years (Llagostera and Costa 1999). They range in time from 250 to $1240 \mathrm{AD}$. Solcor-3 has two components: a pre-Tiwanaku section (250 to $480 \mathrm{AD})$ and one representing the period under the apex influence of Tiwanaku (480 to 920 AD). Details about this site can be found in Llagostera et al. (1988). Coyo-3 represents the period of final influence of Tiwanaku (Costa and Llagostera 1994). In fact, Coyo-3 is dated from 910 to 960, overlapping with the previous and later periods (Table 1). In that sense, Coyo represents exactly the transition between apex and post Tiwanaku influence in San Pedro de Atacama. Quitor-6 represents the post-Tiwanaku period (pre-Inca); this site is dated from 920 to 1240 AD. Details about Quitor-6 can be found in Costa (1988). This burial site coincides with the peak of a drought in the Central Andes (Berenguer 2000; Binford et al. 1997).

All skeletons were screened for visible marks of infectious disease in the major anatomical parts of the body (cranium, ribs, sternum, shoulder girdle, arms, hands, pelvis, legs and feet) by two of the authors (WAN and MAC). Ortner and Putschar (1981) were used as the standard of reference in the osteological analysis. In the case of the skull, alveolar infections (abscesses) were not included here. No attempt was made to identify the specific etiology of the infections or to associate specific pathogens to specific kinds of lesions. The infections were classified in two main groups: periostitis and osteomyelitis. These terms are used here as general descriptive categories (Ortner and Putschar 1981).

Periostitis was defined as any trace of infection restricted to the surface of the bone, while

Table 1. General characteristics of the skeletal series included in the study.

Características generales de la serie esqueletal incluida en el estudio.

\begin{tabular}{|c|c|c|c|c|c|c|}
\hline Periods & Sites & Male & Female & $\mathrm{Na}$ & Ns & Chronology* \\
\hline \multirow[t]{2}{*}{ Pre-Tiwanaku } & Solcor-3 & 21 & 16 & 37 & 13 & $250 \pm 150 \mathrm{AD}$ \\
\hline & & & & & & $480 \pm 60 \mathrm{AD}$ \\
\hline \multirow[t]{2}{*}{ Apex-Tiwanaku } & Solcor-3 & 18 & 22 & 40 & 18 & $480 \pm 80 \mathrm{AD}$ \\
\hline & & & & & & $920 \pm 120 \mathrm{AD}$ \\
\hline \multirow[t]{2}{*}{ Final-Tiwanaku } & Coyo-3 & 24 & 22 & 46 & 18 & $910 \pm 70 \mathrm{AD}$ \\
\hline & & & & & & $960 \pm 50 \mathrm{AD}$ \\
\hline \multirow[t]{2}{*}{ Post-Tiwanaku } & Quitor-6 & 11 & 22 & 33 & 39 & $920 \pm 70 \mathrm{AD}$ \\
\hline & & & & & & $1,240 \pm 70 \mathrm{AD}$ \\
\hline
\end{tabular}

$\mathrm{Na}=$ number of adult skeletons analyzed;

Ns = number of subadult skeletons analyzed.

* adapted from Costa et al. 2004. 


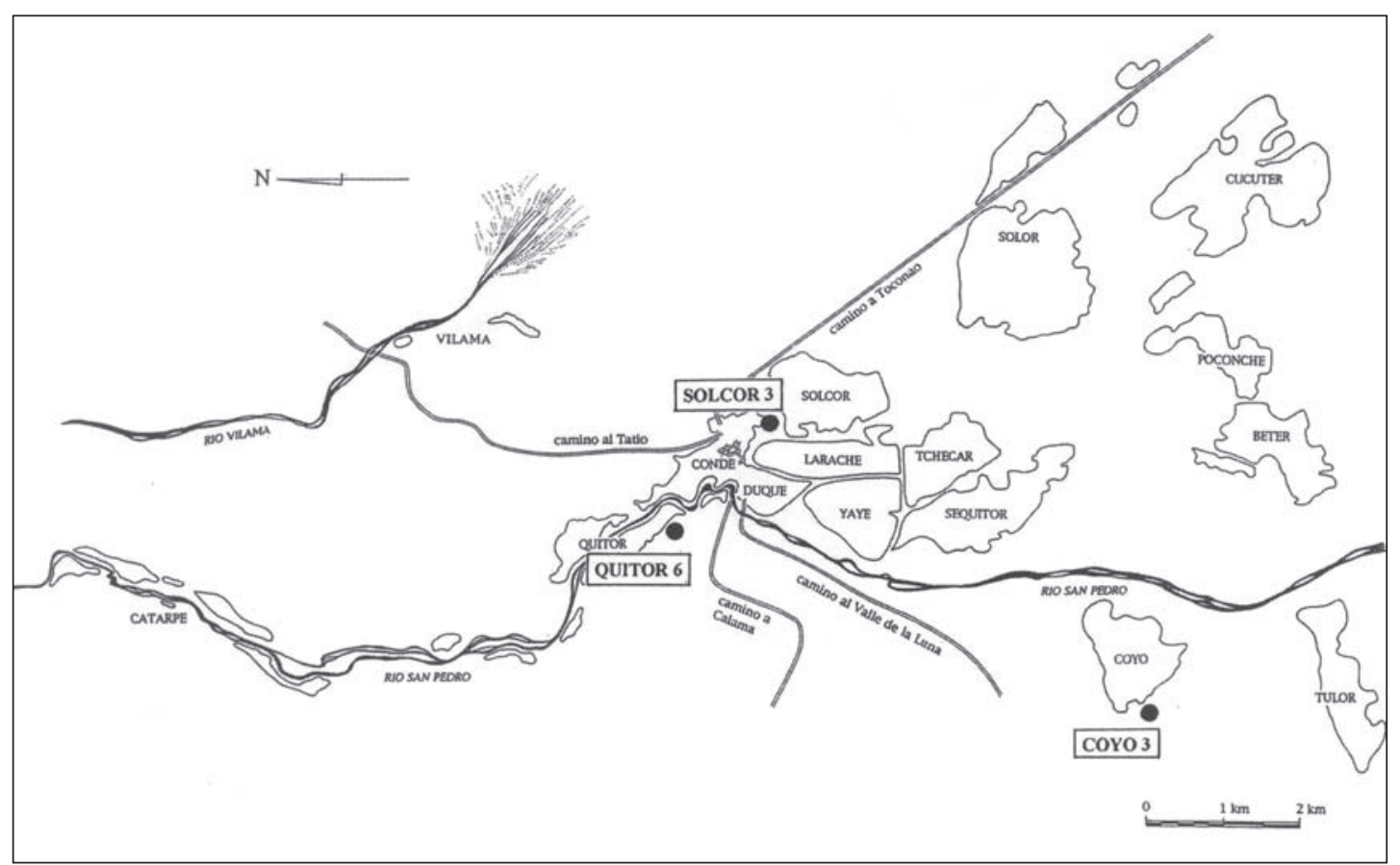

Figure 2. Detailed map of the Atacama Salar showing the three sites analyzed (adapted from Costa et al. 2004). Detalle del mapa del salar de Atacama mostrando los tres sitios analizados (adaptado de Costa et al. 2004).

osteomyelitis was defined as any trace of infection which invaded the medullar cavity (Birkett 1983; Kelley 1989; Ortner and Putschar 1981). In the first case, visual inspection focused on any sign of periosteal reaction and inflammation. These included the formation of sclerotic bone and thickening of the periosteal layer not associated with callus formation derived from trauma. In the case of osteomyelitis, visual inspection focused on signs of sequestra and of cloacal openings entering the medullar cavity since these lesions result from the introduction of pyogenic bacteria into the bone (Brothwell and Sandison 1967; Ortner and Putschar 1981; Steinbock 1976). Both kinds of infections were classified in two categories: "minor" if it involved less than one third of a bone or "extensive" if more than one third of the bone area was involved.

The data were processed using either bones or individuals as units of analysis. In this paper, due to space restrictions, we concentrate on the figures derived from using individuals as the unit of analysis. In this case two states for each individual were considered: affected or not affected. Only one infected bone was sufficient to consider the individual as affected. This approach has the advantage of considering the individual as a whole, avoiding fragmentation of data, since it is the individual and not the bone that becomes sick. On the other hand, this strategy has the disadvantage of not considering grades of infection. Taking into account this limitation, we also included an analysis using grades of infection. The percentage of bones infected per individual was calculated. These figures were used to generate a mean frequency for each period. Only infected individuals were included in this second strategy, and the four categories of infections were joined into one. Only sub-adults were processed in this case, since the data of adults we collected are not available to publication yet.

The analyses of adults and of sub-adults were done separately. In the case of the adults, data processing also included differences between sexes within each period.

\section{Results}

Table 2 presents the prevalence of infectious disease in adults by sex for the four periods analyzed. Fisher's Exact Test was applied to investigate the differences between sexes within each period. None of the comparisons reached statistical significance utilizing 5\% p-value significance (data not shown). 
Table 2. Incidence of nonspecific infectious diseases in adults by period and sex. Incidencia de enfermedades infecciosas no-específicas en adultos por períodos y por sexo.

\begin{tabular}{|c|c|c|c|c|c|c|c|c|c|c|c|c|c|c|c|c|}
\hline \multirow{3}{*}{ Type of Infection } & \multicolumn{4}{|c|}{ Pre-Tiwanaku } & \multicolumn{4}{|c|}{ Apex-Tiwanaku } & \multicolumn{4}{|c|}{ Final-Tiwanaku } & \multicolumn{4}{|c|}{ Post-Tiwanaku } \\
\hline & \multicolumn{2}{|c|}{ Males } & \multicolumn{2}{|c|}{ Females } & \multicolumn{2}{|c|}{ Males } & \multicolumn{2}{|c|}{ Females } & \multicolumn{2}{|c|}{ Males } & \multicolumn{2}{|c|}{ Females } & \multicolumn{2}{|c|}{ Males } & \multicolumn{2}{|c|}{ Females } \\
\hline & $\mathrm{F}$ & $\%$ & $\mathrm{~F}$ & $\%$ & $\mathrm{~F}$ & $\%$ & $\mathrm{~F}$ & $\%$ & F & $\%$ & $\mathrm{~F}$ & $\%$ & F & $\%$ & $\mathrm{~F}$ & $\%$ \\
\hline Minor Periostitis & $10 / 21$ & 47.61 & $7 / 16$ & 43.75 & $8 / 18$ & 44.44 & $12 / 22$ & 54.54 & $5 / 24$ & 20.83 & $4 / 22$ & 18.18 & $9 / 11$ & 81.82 & $16 / 22$ & 72.73 \\
\hline Extensive Periostitis & $4 / 21$ & 19.05 & $4 / 16$ & 25.00 & $4 / 18$ & 22.22 & $3 / 22$ & 13.64 & $5 / 24$ & 20.83 & $6 / 22$ & 27.27 & $1 / 11$ & 9.09 & $0 / 22$ & 0.00 \\
\hline Minor Osteomyelitis & $2 / 21$ & 9.52 & $1 / 16$ & 6.25 & $2 / 18$ & 11.11 & $6 / 22$ & 27.27 & $1 / 24$ & 4.17 & $1 / 22$ & 4.54 & $6 / 11$ & 54.54 & $4 / 22$ & 18.18 \\
\hline Extensive Osteomyelitis & $0 / 21$ & 0.00 & $0 / 16$ & 0.00 & $0 / 18$ & 0.00 & $1 / 22$ & 4.54 & $0 / 24$ & 0.00 & $1 / 22$ & 4.54 & $0 / 11$ & 0.00 & $1 / 22$ & 4.54 \\
\hline
\end{tabular}

Table 3. Incidence of nonspecific infectious diseases in adults by period (sexes pooled). Incidencia de enfermedades infecciosas no-específicas en adultos por períodos (sexos agrupados).

\begin{tabular}{|c|c|c|c|c|c|c|c|c|}
\hline \multirow{2}{*}{ Type of Infection } & \multicolumn{2}{|c|}{ Pre-Tiwanaku } & \multicolumn{2}{|c|}{ Apex-Tiwanaku } & \multicolumn{2}{|c|}{ Final-Tiwanaku } & \multicolumn{2}{|c|}{ Post-Tiwanaku } \\
\hline & $\mathrm{F}$ & $\%$ & $\mathrm{~F}$ & $\%$ & $\mathrm{~F}$ & $\%$ & $\mathrm{~F}$ & $\%$ \\
\hline Minor Periostitis & $17 / 37$ & 45.94 & $20 / 40$ & 50.00 & $9 / 46$ & 19.56 & $25 / 33$ & 75.75 \\
\hline Extensive Periostitis & $8 / 37$ & 21.62 & $7 / 40$ & 17.05 & $11 / 46$ & 23.91 & $1 / 33$ & 3.03 \\
\hline Minor Osteomyelitis & $3 / 37$ & 8.11 & $8 / 40$ & 20.00 & $2 / 46$ & 4.34 & $10 / 33$ & 30.30 \\
\hline Extensive Osteomyelitis & $0 / 37$ & 0.00 & $1 / 40$ & 2.50 & $1 / 46$ & 2.17 & $1 / 33$ & 3.03 \\
\hline
\end{tabular}

This result allows us to state that males and females were equally prone to bone infections throughout the four periods analyzed.

Table 3 presents the incidence for the four categories of bone infection by period with sexes pooled. The same information is graphically depicted in Figure 3. Table 4 presents the results of the sub-adults.

As can be seen, "minor periostitis" was, in general, the most frequent bone infection observed in San Pedro de Atacama, while "extensive osteomyelitis" was the least. This is in agreement with previous knowledge about these pathological lesions: localized periostitis can be easily produced by local wounds, while osteomyelitis demands either the rupture of the periosteum or a systemic infection in order to affect a bone (Brothwell and Sandison 1967; Goodman and Martin 2002; Larsen 1999; Ortner and Putschar 1981; Steinbock 1976).

Tables 3 and 5 and Figure 3 show a strong variation in the incidence of "minor periostitis" in adults among periods. With the exception of the comparison between pre-Tiwanaku and apexTiwanaku, all other comparisons reached statistical significance. In other words, the incidence during the apex influence of Tiwanaku did not change the picture when compared to the previous period. However, the apex influence period was followed by a significant decrease in the final-Tiwanaku phase. The high occurrence of bone infections in the post-Tiwanaku period is remarkable (Quitor-6) considering that almost $76 \%$ of the adult population was affected.

Tables 3 and 6 and Figure 3 show that the prevalence of "extensive periostitis" in adults was approximately the same from pre to final-Tiwanaku (no statistically significant differences were found when the three periods involved were compared). The post-Tiwanaku period witnessed a significant decrease in the incidence of this pathological lesion (differences attained statistical significance when compared with pre and final Tiwanaku). Considering that the prevalence of "minor" periostitis in the post-Tiwanaku period was high, the explanation for the decrease of "extensive" periostitis in that period remains uncertain. Although we could consider "minor" and "extensive" infections as different degrees of the same phenomenon, this relation, as can be seen here, is not so simple.

Tables 3 and 7 and Figure 3 show no significant difference in the occurrence of "minor osteomyelitis" in adults when pre-Tiwanaku and apex-Tiwanaku times are compared. Great changes in the frequencies of "minor osteomyelitis" occurred after the peak of Tiwanaku influence. Final-Tiwanaku presented 


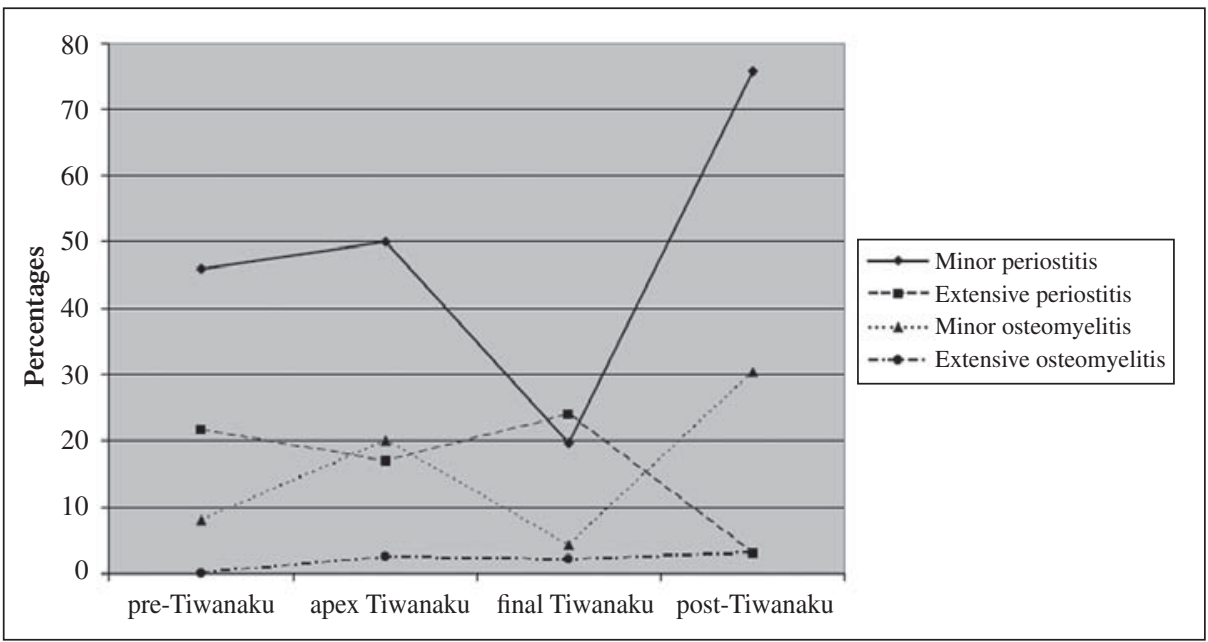

Figure 3. Incidence of nonspecific infectious diseases in adults by period.

Incidencia de enfermedades infecciosas no-específicas en adultos por períodos.

a significant decrease in the rate of occurrence when compared with both apex-Tiwanaku and postTiwanaku (again, the most affected sample).

The extremely low frequencies of "extensive osteomyelitis" compared to other categories of infections in the adults of San Pedro de Atacama (Table 3 and Figure 3) suggest a strong resistance of the local population to pathogens leading to severe bone infections. The rate of occurrence of this category showed no significant difference among periods (Table 8).

The results with the sub-adults are similar to those of the adults (Table 4, Figure 4). "Minor periostitis" and "minor osteomyelitis" show a marked decrease in the final Tiwanaku. "Extensive periostitis" exhibits approximately the same pattern as the adults, with the exception of a decrease in the pre-Tiwanaku and an increase in the postTiwanaku period. As in the case of adults, "extensive osteomyelitis" presents the lowest frequencies of the four categories in sub-adults, although the values of pre and apex Tiwanaku in sub-adults are higher than in adults. None of the Exact Tests of Fisher performed among the periods (data not shown) produced significant results.

The analysis of sub-adult skeletons using grades of infection is presented in Table 9 and Figure 5. They show the same basic pattern observed above: apex-Tiwanaku with the highest percentage (17.15\%) and final Tiwanaku with the lowest $(3.81 \%)$. The statistic test ANOVA no parametric (Kruskal-Wallis) did not produce a significant result using 5\% p-value significance $(\mathrm{Kw}=2.344 ; \mathrm{p}$-value $=0.5041)$. It is important to highlight, however, the similarity between the data for adults and sub-adults. This coincidence leads to a single pattern of infection, even with the lack of statistic significance for the sub-adults.

Table 4. Incidence of nonspecific infectious diseases in subadults by period. Incidencia de enfermedades infecciosas no-específicas en subadultos por período.

\begin{tabular}{|c|c|c|c|c|c|c|c|c|}
\hline \multirow{2}{*}{ Periods } & \multicolumn{2}{|c|}{ Pre-Tiwanaku } & \multicolumn{2}{|c|}{ Apex-Tiwanaku } & \multicolumn{2}{|c|}{ Final-Tiwanaku } & \multicolumn{2}{|c|}{ Post-Tiwanaku } \\
\hline & $\mathrm{F}$ & $\%$ & $\mathrm{~F}$ & $\%$ & $\mathrm{~F}$ & $\%$ & $\mathrm{~F}$ & $\%$ \\
\hline Minor Periostitis & $3 / 39$ & 7.69 & $4 / 18$ & 22.22 & $0 / 18$ & 0.00 & $2 / 13$ & 15.38 \\
\hline Extensive Periostitis & $0 / 39$ & 0.00 & $2 / 18$ & 11.11 & $2 / 18$ & 11.11 & $1 / 13$ & 7.69 \\
\hline Minor Osteomyelitis & $4 / 39$ & 10.26 & $3 / 18$ & 16.66 & $0 / 18$ & 0.00 & $3 / 13$ & 23.08 \\
\hline Extensive Osteomyelitis & $3 / 39$ & 7.69 & $1 / 18$ & 5.55 & $0 / 18$ & 0.00 & $0 / 13$ & 0.00 \\
\hline
\end{tabular}




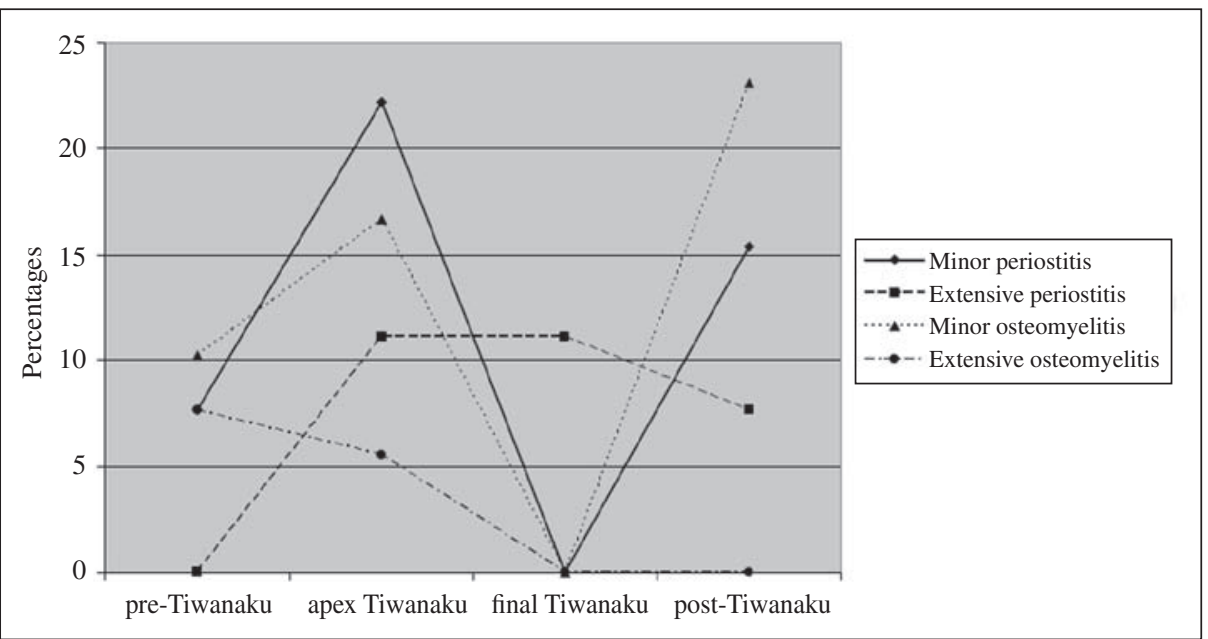

Figure 4. Incidence of nonspecific infectious diseases in sub-adults by period.

Incidencia de enfermedades infecciosas no-específicas en subadultos por períodos.

Table 5. Comparison of incidence (adult skeletons) among periods by means of Fisher's Exact Test (Minor Periostitis). Comparación de la incidencia en esqueletos adultos entre períodos a través del Test Exacto de Fisher (periostitis menor).

\begin{tabular}{cccc}
\hline Periods & $\begin{array}{c}\text { Apex- } \\
\text { Tiwanaku }\end{array}$ & $\begin{array}{c}\text { Final- } \\
\text { Tiwanaku }\end{array}$ & $\begin{array}{c}\text { Post- } \\
\text { Tiwanaku }\end{array}$ \\
\hline Pre-Tiwanaku & 0.8205 & $\mathbf{0 . 0 1 0 0}$ & $\mathbf{0 . 0 1 4 9}$ \\
Apex-Tiwanaku & & $\mathbf{0 . 0 0 3 1}$ & $\mathbf{0 . 0 3 0 8}$ \\
Final-Tiwanaku & & & $<\mathbf{0 . 0 0 0 1}$ \\
\hline
\end{tabular}

Numbers in bold indicate significant differences.

Table 6. Comparison of incidence (adult skeletons) among periods by means of Fisher's Exact Test (Extensive Periostitis).

Comparación de la incidencia en esqueletos adultos entre períodos a través del Test Exacto de Fisher (periostitis extensiva).

\begin{tabular}{cccc}
\hline Periods & $\begin{array}{c}\text { Apex- } \\
\text { Tiwanaku }\end{array}$ & $\begin{array}{c}\text { Final- } \\
\text { Tiwanaku }\end{array}$ & $\begin{array}{c}\text { Post- } \\
\text { Tiwanaku }\end{array}$ \\
\hline Pre-Tiwanaku & 0.7756 & 1.0000 & $\mathbf{0 . 0 3 0 0}$ \\
Apex-Tiwanaku & & 0.5971 & 0.0652 \\
Final-Tiwanaku & & & $\mathbf{0 . 0 1 1 4}$ \\
\hline
\end{tabular}

Numbers in bold indicate significant differences
Table 7. Comparison of incidence (adult skeletons) among periods by means of Fisher's Exact Test (Minor Osteomyelitis).

Comparación de la incidencia en esqueletos adultos entre períodos a través del Test Exacto de Fisher (osteomielitis menor).

\begin{tabular}{cccc}
\hline Periods & $\begin{array}{c}\text { Apex- } \\
\text { Tiwanaku }\end{array}$ & $\begin{array}{c}\text { Final- } \\
\text { Tiwanaku }\end{array}$ & $\begin{array}{c}\text { Post- } \\
\text { Tiwanaku }\end{array}$ \\
\hline Pre-Tiwanaku & 0.1956 & 0.3192 & $\mathbf{0 . 0 2 9 0}$ \\
Apex-Tiwanaku & & $\mathbf{0 . 0 1 0 7}$ & 0.4146 \\
Final-Tiwanaku & & & $\mathbf{0 . 0 0 0 5}$ \\
\hline
\end{tabular}

Numbers in bold indicate significant differences.

Table 8. Comparison of incidence (adult skeletons) among periods by means of Fisher's Exact Test (Extensive Osteomyelitis).

Comparación de la incidencia en esqueletos adultos entre períodos, a través del Test Exacto de Fisher (osteomielitis extensiva).

\begin{tabular}{cccc}
\hline Periods & $\begin{array}{c}\text { Apex- } \\
\text { Tiwanaku }\end{array}$ & $\begin{array}{c}\text { Final- } \\
\text { Tiwanaku }\end{array}$ & $\begin{array}{c}\text { Post- } \\
\text { Tiwanaku }\end{array}$ \\
\hline Pre-Tiwanaku & 1.0000 & 1.0000 & 0.4714 \\
Apex-Tiwanaku & & 1.0000 & 1.0000 \\
Final-Tiwanaku & & & 1.0000 \\
\hline
\end{tabular}




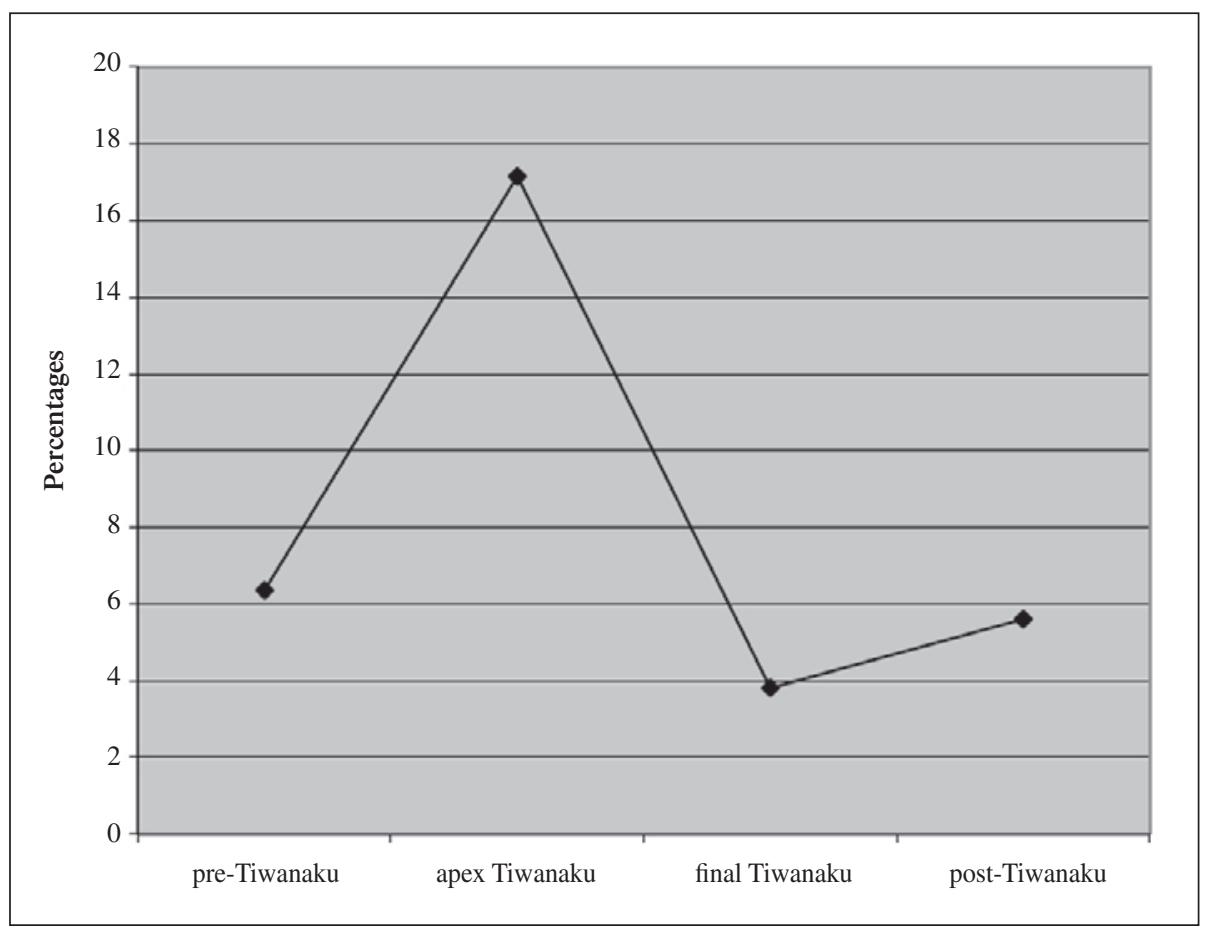

Figure 5. Percentage of infected bones per individual (mean) in sub-adults by period.

Porcentaje de huesos afectados por individuo (promedio) en subadultos por períodos.

Table 9. Comparison of means (sub-adult skeletons) of bones affected by nonspecific infections among periods and respective samples.

Comparación de los promedios (esqueletos subdultos)

de huesos afectados por enfermedades infecciosas noespecíficas por períodos y respectivas muestras.

\begin{tabular}{ccc}
\hline Periods & Sample & Mean $(\%)$ \\
\hline Pre-Tiwanaku & 8 & 6.36 \\
Apex-Tiwanaku & 5 & 17.15 \\
Final-Tiwanaku & 2 & 3.81 \\
Post-Tiwanaku & 5 & 5.61 \\
\hline
\end{tabular}

\section{Discussion and Conclusions}

A potential bias in the interpretation of the results obtained is the difference of socioeconomic status between the samples. The work of Costa and Neves (1990) approached this subject through a Principal Components Analysis. They crossed data from biological markers of quality of life and mortuary associations. No association between social status and quality of life was obtained. However, only burials from the site Quitor-6 (post-Tiwanaku) were included in their analysis. This kind of information is not available for the remaining sites. Furthermore, Neves and Costa (1998) found a stature increase during apex-Tiwanaku. This increase was spread across all the population, independent of social status differences. Therefore, the data available do not point to a sample bias caused by socioeconomic status, since no correlation was found between social status and quality of life at San Pedro de Atacama.

Another problem is the "osteological paradox" (Wood et al. 1992), which questions the traditional interpretation of the osteological markers of quality of life. In accordance with Wood et al. (1992), an archaeological sample does not fully correspond to the living population from which the sample is derived. The skeletons would represent the more frail individuals in the population, and, consequently, their health would be worse than that of the living population. One implication of this paradox is that more frail individuals would die before marks in the skeleton developed. Accordingly, the osteological paradox states that absence of lesion can signify bad health. The traditional view, on the other hand, does not consider this phenomenon an obstacle for interpreting osteological markers. The traditional view assumes that the effect of the osteological 
paradox is not strong enough to confuse the interpretation (Goodman 1993). Bioarchaeologists have many difficulties deciding between these two forms of data interpretation (traditional versus paradox), mainly because few studies have dealt with this problem directly. Two studies that treated this subject showed that the paradox had limited influence upon the osteological markers, one focusing on stature (Saunders and Hoppa 1993), and the other on several markers (Bennike et al. 2005). Here, we will adopt the traditional interpretation.

In the beginning of this paper, we stated that the influence of Tiwanaku was a major cause of cultural and economic change experienced by the Atacameños in prehistoric times. The available archaeological information points to remarkable economic improvement for the Atacameño people at this time. Apparently, population disruption and violent coercion were not used by Tiwanaku to involve the local population of San Pedro de Atacama in its sphere of influence (Torres-Rouff and Costa 2006). Skeletal data already available reveal a significant increase in adult stature in the region during the same period (Neves and Costa 1998), not to mention lower rates of tooth wear and dental caries (Costa et al. 2004).

The assessment of bone infections carried out in this article does not allow us, however, to conclude that the local population had benefited from a better epidemiological milieu during the apex-Tiwanaku period. Our results show that when compared with pre-Tiwanaku times, the period under the altiplanic influence showed no improvement in terms of infectious diseases affecting bones. In fact, the best epidemiological milieu in regards to these pathological conditions was reached in San Pedro de Atacama during the final phase of Tiwanaku influence, with a worsening in later times.

According to Scrimshaw (1964), episodes of acute and chronic nutritional inadequacy render the individual more prone to infectious disease. Accordingly, a smaller prevalence of bone infections during the apex of Tiwanaku influence was expected since this was when the local population experienced improved nutrition, probably by means of more protein intake. We propose two reasons for explaining this apparent incongruence. The improved nutritional conditions could have been counteracted by worsened sanitary conditions derived from population growth and aggregation and/ or by more frequent contact with foreign pathogens.
The first possibility has been amply accepted by North American physical anthropologists to explain the large increase in the rate of bone infections in Amerindians under the process of sedentarization, adoption of agriculture, and demographic increase (see Cohen and Armelagos 1984 for the classic discussions of this association).

Very little is known about the demographic profile of the Atacameños in any of the periods under analysis. However, two studies shed some light on this matter. Llagostera and Costa (1999) located and studied a series of habitation sites in the Salar de Atacama. They showed that, during the influence of Tiwanaku, the number of human settlements in the region increased significantly when compared to other periods, suggesting a high demographic density, mainly between 700 and 920 AD. After this period, San Pedro de Atacama suffered an accentuated decrease in the number of settlements, probably as a response to the disruption of Tiwanaku and the drought that affected the region. Varela and Cocilovo (2000) demonstrated that during the influence of Tiwanaku, the population of San Pedro de Atacama presented more biological variability, reinforcing the idea of a larger population size and/ or more biological contact and interchange with foreign populations. Thus, it is feasible that while the economic and nutritional improvement during the Tiwanaku influence stimulated higher rates of reproduction and survivorship, population density and contact with alien populations increased the rate of infection by deleterious micro-organisms. The only problem with this hypothesis is to explain how a highly infected population could still benefit from a richer diet, as reflected by body growth.

Little is known about the relationship between bacterial bone disease and body growth impairment. Most of the literature regarding the association between body growth impairment and infections refers to intestinal parasites, respiratory and endemic diseases (e.g. Sattenspiel 2000; Wilson et al. 1999). Moffat (2003) conducted a study in Kathmandu, Nepal proposing that it is necessary to distinguish between viral and bacterial diarrhea, and protozoan gastrointestinal parasites. The former is acute and shows no correlation with body growth impairment, while the second is more chronic and is linked with low stature. It seems that in acute infections the body has the possibility of experiencing catch up growth. Moffat also concluded that respiratory infections did not significantly impact the final stature of the target population. 
Places in high altitudes, like San Pedro de Atacama $(2,400 \mathrm{~m})$, are said to show low rates of intestinal parasitism. Studies focusing on paleoparasitology found hookworms (Ancylostoma duodenale), whipworms (Trichuris trichiura), pinworms (Enterobius vermicularis), Trichostongylus spp., Paragonimus spp. and Entamoeba spp. in coprolites recovered in the region of San Pedro de Atacama (Gonçalves et al. 2003). However, we don't know the frequency of these parasites in the local population. What we know is that most of these parasites need warm and moist soil to survive outside of the human body. Martinson et al. (2003) found a low frequency of parasites in the Chiribaya culture (700-1,350 AD), southern Peru, but still within the Atacama Desert. The authors concluded that aridity would be the best explanation for the figures they found. Ubelaker (1992) explained lower rates of porotic hyperostosis in the highlands of Ecuador, when compared to the lowlands, by a lower incidence of intestinal parasitism at high altitudes. Another study related to this issue was conducted by Blom et al. (2005) along the coast of pre-Columbian Peru. They studied the prevalence of porotic hyperostosis in a sample of 1465 individuals from an extensive area of that country. They found a negative correlation between altitude and porotic hyperostosis and a positive correlation between humidity and porotic hyperostosis. These results were explained by a low prevalence of parasitism in high altitude and dry weather. These same circumstances characterize San Pedro de Atacama. The fact that intestinal parasitism is very deleterious to body growth (Moffat 2003) suggests that in San Pedro de Atacama, high stature was a consequence of "good diet" and "less parasitism", and that bone infection, mainly minor periostitis and osteomyelitis (the predominant ones), had little impact on human final stature.

The decrease in the rate of bone infections during the final period of influence of Tiwanaku is difficult to explain with the available information. What is known for sure is that population density and aggregation in this period decreased (Llagostera and Costa 1999). In fact, population density presents a positive correlation with prevalence of infections (Larsen 1999).

As long distance trading significantly intensified during the apex-Tiwanaku period with the establishment of new routes of exchange, the Atacameño people were exposed to completely new pathogens or to new strains of traditional ones. Density and aggregation also increased during the same period. An explanation for the low rates of bone infection in the final moments of influence of Tiwanaku in San Pedro remains uncertain, but it should be a combination of complex factors acting in a transitional period. After completely ceasing the influence of Tiwanaku in San Pedro de Atacama, the rate of bone infections rose; drought and shortage of food items seem to have been the main factors behind this peak of infection.

Acknowledgements: This research was financed by CNPq (Brasil) and CONICYT (Chile). Walter Neves held a scholarship from CNPq (Process 305918/85-0) while preparing the manuscript. Pedro Da-Glória held a master scholarship from FAPESP (process 04/04054-9) during the same period. We are deeply indebted to Agustin Llagostera for his support and for sharing with us his extensive knowledge about the prehistory of San Pedro de Atacama. We also acknowledge the anonymous reviewers and the editors of Chungara for giving us important comments and suggestions.

\section{References Cited}

Bennike, P., M.E. Lewis, H. Shutkowski, and F. Valentin 2005 Comparison of child morbidity in two contrasting medieval cemeteries from Denmark. American Journal of Physical Anthropology 128:734-746.

Berenguer, J.

2000 Tiwanaku: Señores del Lago Sagrado. Museo Chileno de Arte Precolombino, Santiago.

Bermann, M.

1997 Domestic life and vertical integration in the Tiwanaku heartland. Latin American Antiquity 8:93-112.

Binford, M.W., A.L. Kolata, M. Brenner, J.W. Janusek, M.T. Seddon, M. Abbott, and J.H. Curtis
1997 Climate variation and the rise and fall of an Andean civilization. Quaternary Research 47:235-248.

Birkett, D.A.

1983 Non-specific infections. In Disease in Ancient Man, edited by G.D. Hart, pp. 99-105. Clarke Irwin, Toronto.

Blom, D.E., J.E. Buikstra, L. Keng, P.D. Tomczak, E. Shoreman. and D. Stevens-Tuttle

2005 Anemia and childhood mortality: Latitudinal patterning along the coast of pre-Columbian Peru. American Journal of Physical Anthropology 127:152-169.

Brothwell, D.R., and A.T. Sandison, editors 1967 Diseases in Antiquity. C.C. Thomas, Springfield. 
Browman, D.L.

1980 Tiwanaku expansion and altiplano economic patterns. Estudios Arqueológicos 5:107-120.

Cohen, M.N., and G.J. Armelagos, editors 1984 Paleopathology at the Origins of Agriculture. Academic Press, New York.

Costa, M.A.

1988 Reconstitución física y cultural de la población tardía del cementerio de Quitor-6 (San Pedro de Atacama). Estudios Atacameños 9:99-126.

Costa, M.A., and A. Llagostera 1994 Coyo-3: momentos finales del período medio en San Pedro de Atacama. Estudios Atacameños 11:73-107.

Costa, M.A., and W.A. Neves 1990 Osteobiography and late agriculture social organization at San Pedro de Atacama, Chile. Presented in 59 Annual Meeting of American Association of Physical Anthropologists, Miami

Costa, M.A., W.A. Neves and M. Hubbe

2004 Influencia de Tiwanaku en la calidad de vida biológica de la población prehistórica de San Pedro de Atacama. Estudios Atacameños 27:103-116.

Gonçalves, M.L.C., A. Araújo, and L.F. Ferreira

2003 Human intestinal parasites in the past: new findings and a review. Memórias do Instituto Oswaldo Cruz 98 (Suppl. 1):103-118.

Goodman, A.H.

1993 On the interpretation of health from skeletal remains. Current Anthropology 34:281-288.

Goodman, A.H., and D.L. Martin

2002 Reconstructing health profiles from skeletal remains. In The Backbone of History: Health and Nutrition in the Western Hemisphere, edited by R.H. Steckel, and J.C. Rose, pp. 11-60. Cambridge University Press, Cambridge.

Janusek, J.W.

2002 Out of many, one: style and social boundaries in Tiwanaku. Latin American Antiquity 13:35-61.

Kelley, M.A.

1989 Infectious disease. In Reconstruction of Life from the Skeleton, edited by M.Y. Iscan and K.A.R. Kennedy, pp. 129-160. Alan R. Liss., Inc., New York.

Knudson, K.J.

2008 Tiwanaku influence in the South Central Andes: Strontium isotope analysis and Middle Horizon migration. Latin American Antiquity 19:2-23.

Kolata, A.L.

1993 The Tiwanaku: Portrait of an Andean Civilization. Blackwell, Cambridge.

Larsen, C.S.

1999 Bioarchaeology: Interpreting Behavior from the Human Skeleton. Cambridge University Press, Cambridge.

Le Paige, G.

1965 San Pedro de Atacama y sus zonas. Anales de la Universidad del Norte 4:1-99.

Llagostera, A.

1996 San Pedro de Atacama: nodo de complementariedad reticular. Estudios y Debates Regionales Andinos 91:1742.

2004 Los Antiguos Habitantes del Salar de Atacama: Prehistoria Atacameña. Pehuén Editores, Santiago.
Llagostera, A., and M.A. Costa

1984 Museo Arqueológico R. P. Le Paige, S. J. Serie Patrimonio Cultural Chileno, Colección Museos Chilenos. Ministerio de Educación, Santiago.

1999 Patrones de asentamiento en la época agroalfarera de San Pedro de Atacama (norte de Chile). Estudios Atacameños 17:175-206.

Llagostera, A., C.M. Torres, and M.A. Costa

1988 El complejo psicotrópico en Solcor-3 (San Pedro de Atacama). Estudios Atacameños 9:61-98.

Martinson, E., K.J. Reinhard, J.E. Buikstra, and K.D. Cruz 2003 Pathoecology of Chiribaya parasitism. Memórias do Instituto Oswaldo Cruz 98(Suppl. 1):195-205.

Moffat, T.

2003 Diarrhea, respiratory infections, protozoan gastrointestinal parasites, and child growth in Kathmandu, Nepal. American Journal of Physical Anthropology 122:85-97.

Neves, W.A., and M.A. Costa

1998 Adult stature and standard of living in the prehistoric Atacama Desert. Current Anthropology 39:278-281.

Neves, W.A., M.A. Costa-Junqueira, R.A. Salm, and R.G.T. Cunha

1996 Osteology of social organization in San Pedro de Atacama: Trauma and social tension. Presented in IV Congreso de la Asociación Latino-Americana de Biología Antropológica, Buenos Aires.

Neves, W.A., M. Hubbe, and M.A. Costa

2000 Marcadores dentários de dieta e mudança social em San Pedro de Atacama, Chile. Presented in VI Congreso de la Asociación Latino-Americana de Biología Antropológica, Piriápolis.

Núñez, L.

1992 Cultura y Conflicto en los Oasis de San Pedro de Atacama. Editorial Universitaria, Santiago.

Ortloff, C.R., and A.L. Kolata

1993 Climate and collapse: Agro-ecological perspectives on the decline of the Tiwanaku State. Journal of Archaeological Science 20:195-221.

Ortner, D.J., and W.G.J. Putschar

1981 Identification of Pathological Conditions in Human Skeletal Remains. Smithsonian Institution Press., Washington \& London.

Rodman, A.O.

1992 Textiles and ethnicity: Tiwanaku in San Pedro de Atacama, North Chile. Latin American Antiquity 3:316-340.

Sattenspiel, L.

2000 Tropical environments, human activities, and the transmission of infectious disease. Yearbook of Physical Anthropology 43:3-31.

Saunders, S.R., and R.D. Hoppa

1993 Growth deficit in survivors and non-survivors: Biological mortality bias in subadult skeletal samples. Yearbook of Physical Anthropology 36:127-151.

Scrimshaw, N.S.

1964 Ecological factors in nutritional diseases. American Journal Clinical Nutrition 14:112-122.

Stanish, C.S., and L. Steadmen

1994 Archaeological research at Tumatumani, Juli, Peru. Fieldiana Anthropology 23. 
Steckel, R.H.

1995 Stature and the standard of living. Journal of Economic Literature 33:417-426.

Steinbock, R.T.

1976 Paleopathological Diagnosis and Interpretation. C. C. Thomas, Springfield.

Torres-Rouff, C.

2008. The influence of Tiwanaku on life in the Chilean Atacama: mortuary and bodily perspectives. American Anthropologist 110:325-337.

Torres-Rouff, C., and Costa M.A.

2006 Interpersonal violence in prehistoric San Pedro de Atacama, Chile: behavioral implications of environmental stress. American Journal of Physical Anthropology 130:60-70.
Ubelaker, D.H.

1992 Porotic hyperostosis in prehistoric Ecuador. In Diet, Demography, and Disease: Changing Perspectives on Anemia, edited by P. Stuart-Macadam and S. Kent, pp. 201-217. Aldine de Gruyter, New York.

Varela, H.H., and J.A. Cocilovo

2000 Structure of the prehistoric population of San Pedro de Atacama. Current Anthropology 41:125-132.

Wilson, W.M., D.L. Dufour, L.K. Staten, M. Barac-Nieto, J.C. Reina, and G.B. Spurr

1999 Gastrointestinal parasitic infection, anthropometrics, nutritional status, and physical work capacity in Colombian boys. American Journal of Human Biology 11:763-771.

Wood, J.W., G.R. Milner, H.C. Harpending, and K.M. Weiss 1992 The osteological paradox. Current Anthropology 33:343370. 